\title{
P05.11. Time, touch, and compassion: effects on autonomic nervous system and well-being
}

\author{
K Kemper ${ }^{*}$, H Shaltout, J Tooze, E Rosenberger \\ From International Research Congress on Integrative Medicine and Health 2012 \\ Portland, Oregon, USA. 15-18 May 2012
}

\section{Purpose}

Compassion is critical for complementary and conventional care. This study tested the feasibility of delivering two doses of time (10 and 20 minutes) and two strategies (tactile and non-tactile) for a practitioner to nonverbally communicate compassion (NVCC) to subjects blind to the interventions.

\section{Methods}

Healthy volunteers were informed that the study was testing the effects of time and touch on the autonomic nervous system. Each subject underwent 5 sequential study periods in one study session: (1) Warm-up; (2) Control - with the practitioner while both read neutral material; (3) Rest; (4) Intervention - with practitioner meditating on lovingkindness toward the subject; and (5) Rest. Subjects were randomized to receive one of four interventions: a) 10 minutes tactile; b) 20 minutes tactile; c) 10 minutes non-tactile; or d) 20 minutes nontactile. During all NVCC interventions, the practitioner meditated on lovingkindness toward the subject. For tactile interventions, the practitioner touched subjects on arms, legs, and hands; for non-tactile interventions, the practitioner pretended to read. Subjects were monitored continuously for autonomic activity. Subjects completed visual analog scales (VAS) for well-being, including relaxation and peacefulness, at warm-up; postcontrol; immediately post-intervention; and after the post-intervention rest.

\section{Results}

The 20 subjects' mean age was $24.3 \pm 4$ years; 16 were women. The practitioner maintained a meditative state during all interventions as reflected in lower RR, and subjects remained blind to the practitioner's meditative

Wake Forest University Health Sciences, Winston-Salem, USA activity. Overall, interventions significantly decreased HR and BP $(\mathrm{p}<0.01)$; although other changes did not reach statistical significance, they were in the expected direction, with generally greater effects for the tactile than non-tactile strategies and for 20 minute than 10 minute doses.

\section{Conclusion}

Two strategies are feasible for blinding subjects to nonverbal communication of compassion; even with blinding, non-verbal communication of compassion affects subjects' autonomic nervous system. Replication is desirable in larger samples.

Published: 12 June 2012

\section{doi:10.1186/1472-6882-12-S1-P371}

Cite this article as: Kemper et al:: P05.11. Time, touch, and compassion: effects on autonomic nervous system and well-being. BMC Complementary and Alternative Medicine 2012 12(Suppl 1):P371.

Submit your next manuscript to BioMed Central and take full advantage of:

- Convenient online submission

- Thorough peer review

- No space constraints or color figure charges

- Immediate publication on acceptance

- Inclusion in PubMed, CAS, Scopus and Google Scholar

- Research which is freely available for redistribution
๑ 2012 Kemper et al; licensee BioMed Central Ltd. This is an Open Access article distributed under the terms of the Creative Commons Attribution License (http://creativecommons.org/licenses/by/2.0), which permits unrestricted use, distribution, and reproduction in any medium, provided the original work is properly cited. 